This article has been published in a revised form in Journal of African Law https://doi.org/10.1017/S0021855318000128. This version is published under a Creative Commons CC-BY-NC-ND. No commercial re-distribution or re-use allowed. Derivative works cannot be distributed. (C) SOAS, University of London 2018.

\title{
AFRICAN STATES: THEMES EMERGING FROM THE HUMAN RIGHTS COUNCIL'S UNIVERSAL PERIODIC REVIEW (UPR)
}

\author{
Damian Etone* \\ The University of Adelaide \\ etonedamian@yahoo.com
}

This is an Author's Original Manuscript of an article published by Cambridge University

Press in the Journal of African Law

\begin{abstract}
This article examines the themes emerging from African states engagement with the Universal Periodic Review (UPR) mechanisms of the UN Human Rights Council (HRC). The underlying principles of universality, cooperation and dialogue which guide the review have given African states a renewed sense of engagement with the international human rights institution. Despite the universality of the process, regionalism and cultural relativism are important aspects in the engagement of African states with the UPR mechanism. This article considers the extent to which regionalism and cultural relativism may prevent the UPR from acting as an effective mechanism for human rights enforcement. It examines the potential for the UPR to complement other national, regional and international human rights mechanisms and the danger of state ritualism. These have ramifications on the extent to which the UPR can achieve its goal of improving the human rights situation on the ground in Africa.
\end{abstract}

Keyword: Africa, Universal Periodic Review, Regionalism, Cultural Relativism, Complementarity and Ritualism.

\section{INTRODUCTION}

The UPR is a unique mechanism of the Human Rights Council (HRC) which relies entirely on cooperation and dialogue to implement human rights. Unlike other UN human rights mechanisms, states are the principal actors and reviewers in the UPR mechanism. The review takes place every 4.5 years in three main stages which include the preparation of state reports, review of the state in Geneva and the follow-up process. The four major principles underlying the review include objectivity, universality, cooperation and complementarity ${ }^{1}$ and with the principal objective of

*Damian Etone is a Beacon of Enlightenment $\mathrm{PhD}$ research scholar at the University of Adelaide Law School, Adelaide, Australia. His research focuses on African states and their engagement with the UN Human Rights Council and its Universal Periodic Review Mechanism. Enormous thanks to associate professor Matthew Stubbs and associate professor Laura Grenfell for their relentless commitment to improving the quality of earlier drafts of this article. This article is a part 


\section{Damian Etone}

improving human rights situation on the ground. ${ }^{2}$ The legal basis of the review include the UN Charter, the Universal Declaration of Human Rights, binding human rights treaties, voluntary pledges and commitments made by states and applicable international humanitarian law. ${ }^{3}$ The review equally welcomes the participation of NGOs, albeit limited, during the plenary session of the HRC when a state report is being adopted. ${ }^{4}$ This article examines the themes emerging from African states engagement in the first and second cycles of the review (UPR I and II) and the extent to which it prevents the UPR from acting as an effective mechanism for the enforcement of human rights.

Whether the UPR is an effective mechanism for the enforcement of human rights has been a source of contention among many scholars. Some authors argue that human rights mechanisms that rely on the cooperation of states are weak and cannot meaningfully advance human rights. ${ }^{5}$ Olivier de Frouville argued that the UPR is flawed because it depends on the good will of states and that it does not represent a real progress for the universal human rights protection system. ${ }^{6}$ Furthermore, he advocated for a more confrontational mechanism through the establishment of a World Commission of Human Rights. ${ }^{7}$ In addition, the UPR has been criticized for its tendency to allow states to engage in hollow ritualism which undermines the aspirations of the UPR to comprehensively address human rights violations. ${ }^{8}$

However, exclusive reliance on "strong" enforcement mechanisms would undermine the potential of cooperative mechanisms. Avoiding human rights rhetoric or ritualism does not necessary require "strong" enforcement mechanism. About 25 years ago, Opsahl advocated for the necessity of a "softer approach" rather than the traditional notion of "right-breach-responsibilityprocess-sanction, leading to punishment of any violator or at least to redress for any victim". 9 Kenneth Roth has argued that coercive mechanisms are not suitable to deal with violations of

of the author's $\mathrm{PhD}$ thesis which examined the engagement of African states with the Universal Periodic Review Mechanism of the UN Human Rights Council.

${ }^{1}$ Human Rights Council, Institution Building of the United Nations Human Rights Council, HRC Res. 5/1, UN HRC OR, 5th sess, Annex [IB], UN Doc A/HRC/RES/5/1 paras 3 and 4.

${ }^{2}$ Id at para 4 (a)

${ }^{3}$ Id at para 1; Nadia Bernaz has questioned some of the legal basis for the UPR see Nadia Bernaz "Reforming the UN Human Rights Procedure: A Legal perspective on the Establishment of the Universal Periodic review" in Kevin Boyle New Institutions for Human Rights Protection (2009, Oxford University Press) at 79-82.

${ }^{4}$ Institution Building Resolution of the United Nations Human Rights Council, above at note 1 at para 31.

${ }^{5}$ Makau Mutua "Looking past the Human Rights Committee: An Argument for De-marginalising Enforcement" (1994) 4 Buffalo Human Rights Review 211 at 211-212; Keith Linda Camp "The United Nations International Covenant on Civil and Political Rights: Does It Make a Difference in Human Rights Behavior" (1999) 36/1 Journal of Peace Research 95-118; Hafner-Burton Emilie and Kiyoteru Tsutsui "Justice Lost! The Failure of International Human Rights Law to Matter Where Needed Most" (2007) 44/4 Journal of Peace Research at 407-425.

${ }^{6}$ Olivier de Frouville "Building a Universal System for the Protection of Human Rights" in M.Cherif Bassouni and William A Schabas (eds) New Challenges for the UN Human Rights Machinery: What Future for the UN Treaty Body System and the Human Rights Council Procedures? (2011, Intersentia) at 253-266.

${ }^{7}$ Olivier also supports the establishment of a World Court of Human Rights which would be more confrontational than a World Commission for Human Rights. See Id at 264-265.

${ }^{8}$ See Hilary Charlesworth and Emma Larking (eds) Human Rights and the Universal Periodic Review: Rituals and Ritualism (2015, Cambridge University Press).

${ }^{9}$ Torkel Opsahl "Instruments of Implementation of Human Rights" (1989) 10/2 Human Rights Law Journal 13 at 31-32. 
economic, social and cultural rights, ${ }^{10}$ and this presently reflects many of the recommendations made to African states during the UPR. There has also been evidence that questions the effectiveness of coercive mechanisms. Empirical analysis from 1981-2000 concluded that “economic sanctions deteriorate citizens' physical integrity rights" ${ }^{11}$ especially when directed towards dictatorial regimes. ${ }^{12}$ The UPR mechanism which relies on cooperation and gives the state some degree of control over the process can be sometimes at least as, if not more effective than coercive mechanisms.

Compared to other human rights mechanisms like the treaty bodies, African states have engaged more actively with the UPR. While many states have overdue reports with the treaty bodies, Africa represents the region with the highest number of overdue reports with 89 of such reports more than 10 years overdue. ${ }^{13}$ There is no state in the region without an overdue report. ${ }^{14}$ Even with the African Commission, states like Nigeria, Kenya, Ghana and Namibia have at various times failed to send delegates to the Commission for the examination of their state reports. ${ }^{15}$ In contrasts, the quality of their reports and delegation for the UPR has been remarkable. Majority of the reports have met the guidelines. ${ }^{16}$ Many of their UPR delegations have been composed of legal personnel and some equally demonstrated gender parity as required by resolution 5/1. ${ }^{17}$ For example seven of the 14 Kenyan UPR I delegates were female and eight of the 13 during UPR II. In both UPR delegations, there was a representative from the National Gender and Equality Commission. This indicates a more active engagement with the UPR than with the treaty bodies.

The enthusiasm and level of engagement by Africa states with the UPR can also be contrasted with their engagement with the African Peer Review Mechanism (APRM). ${ }^{18}$ According to McMahon, Busia and Asherio, despite the progress made by the APRM, it faces major challenges among African states such as the "lack of political will and capacity ... and the number of acceded countries 'sitting on the fence' with no serious signals to kick-start the review process

\footnotetext{
${ }^{10}$ Kenneth Roth is the executive director of Human Rights Watch. See Kenneth Roth "Defending Economic, Social and Cultural Rights: Practical Issues Faced by and International Human Rights Organization" (2004) 26/1 Human Rights Quarterly at 63.

${ }^{11}$ Dursun Peksen "Better or Worse? The Effect of Economic Sanctions on Human Rights" (2009) 46/1 Journal of Peace Research at 59. Also relevant is Mohamed Bennouna "Les sanctions économiques des Nations Unies" (2002-I) 200 RCADI 9 at $40-47$.

${ }^{12}$ Cristiane Careniero and Dominique Elden, "Economic Sanctions, Leadership survival and human rights" (2009) 30(3) University of Pennsylvania Journal of International Law at 969.

13 See OHCHR "Status of Late and Non- reporting by state Parties" available at: <http://tbinternet.ohchr.org/_layouts/TreatyBodyExternal/LateReporting.aspx > (last accessed 16 September 2017).

${ }^{14}$ There are presently $28 \mathrm{UN}$ member states without overdue treaty body reports

15 Takele Soboka Bulto “Africa's Engagement with the Universal Periodic Review: Commitment or Capitulation?" in Hilary Charlesworth and Emma Larking (eds) Human Rights and the Universal Periodic Review: Rituals and Ritualism (2015, Cambridge University Press) at 243.

${ }^{16}$ Except South Africa whose report was rejected during the first cycle of the review because it failed to comply with the page limits See Lilian Chenwi South Africa: State of State Reporting under International Human Rights Law (2010, Community Law Centre) at 62.

${ }^{17}$ Human Rights Council Institution Building of the United Nations Human Rights Council, HRC Res. 5/1, UN HRC OR, $5^{\text {th }}$ sess, Annex [IB], UN Doc A/HRC/RES/5/1 at [3k].

${ }^{18}$ In 2003, the African Union established the African Peer Review Mechanism (APRM) as a self-monitoring initiative to promote good governance in Africa. APRM is designed to promote three fundamental values of the African Union: Freedom and Human Rights, Participatory Development, and Accountability and share a similar cooperative framework to the UPR.
} 


\section{Damian Etone}

could dilute the initial enthusiasm and effectiveness of the mechanism overall". ${ }^{19}$ Nineteen African states have not yet signed up to the review and of the 35 African states that have signed up to the APRM, more than half of them are yet to undertake their self-assessment process. ${ }^{20}$ The fact that all African states participated in both cycles of the UPR and engaged in the UPR reporting and interactive dialogue processes is an indication of a greater enthusiasm and level of engagement with the UPR.

Notwithstanding the enthusiasm by African states for the UPR, some of the themes that have emerged from their review during the first and second UPR cycles raise questions on the effectiveness of their participation and the extent to which the UPR can contribute to improve the human rights situation on the ground. These article examines the themes of regionalism, cultural relativism, selectivity, complementarity and ritualism. ${ }^{21}$ This article examines the issue of complementarity in the case of Kenya and ritualism in the case of South Africa. These have ramifications for the UPR mechanism and may either hinder or assist the mechanism in achieving its objective of improving the human rights situation on the ground.

\section{REGIONALISM}

Regionalism generally occurs within an international organisation when a group of interdependent states form a subgroup within the main organisation. ${ }^{22}$ Regionalism is a useful concept to understand membership and voting in the HRC. Voting in the HRC usually reflects the regional positions of the five groups of states that share seats in the HRC. Rosa Freedman stresses the negative influence of regionalism in polarising and undermining the work of the UN. ${ }^{23}$ However, Abebe, a HRC delegate from Ethiopia, argues that "such subgroups are necessary because human rights discourse and practice are skewed towards western experiences, resulting in developing states requiring subgroups to represent their views and allow participation in human rights bodies". ${ }^{24}$ In the UPR process, regionalism has been utilized by African states despite the universality of the review process.

They have mostly adopted a soft approach to the UPR and are more inclined to accept recommendations from African states than from other states. Kenya accepted recommendations

\footnotetext{
19 See Edward McMahon et al "Comparing Peer Reviews: The Universal Periodic Review of the UN Human Rights Council and the African Peer Review Mechanism” (2013) 12 African and Asian Studies 266 at 276.

${ }^{20}$ The African Peer Review Mechanism "13th Anniversary of the African Peer Review Mechanism” (2016), available at: < http://www.aprm-au.org/viewNews?newsId=101> (last accessed 16 September 2017).

${ }^{21}$ It is worth mentioning that some of these themes run through the engagement of other states and are not exclusive to Africa.

${ }^{22}$ Karl Kaiser "The Interaction of Regional Subsystems: Some Preliminary Notes on Recurrent Patterns and the Role of Superpowers" (1968) 21/1 World Politics at 86.

${ }^{23}$ Rosa Freedman "The United Nations Human Rights Council: more of the same?" (2013) 31/2 Wisconsin International Law Journal 208, 209.

${ }^{24}$ Allehone Mulugeta Abebe "Of Shaming and Bargaining: African States and the Universal Periodic Review of the Human Rights Council" (2009) 9/1 Human Rights Law Review 1 at 2.
} 
from Angola and Rwanda to "[c]ontinue its efforts towards the abolition of the death penalty" 25 but rejected recommendations from France and Poland to "[a]bolish the death penalty". ${ }^{26}$ Similarly, it accepted a "softer" recommendation from Abania to "[r]aise public awareness on the abolition of the death penalty..." ${ }^{27}$ but rejected a "tougher" recommendation from Australia to "formalize its moratorium on the death penalty". ${ }^{28}$ Nigeria equally adopted a similar regional approach in its review. During UPR I, it accepted a general recommendation on the death penalty from Benin ${ }^{29}$ but rejected a similar recommendation from western states such as the UK and Sweden. ${ }^{30}$ During Chad's UPR II, Togo and Czech Republic recommended that Chad "Ratify the Optional Convention against Torture and Other Cruel, inhuman or Degrading Treatment or Punishment". ${ }^{31}$ Chad rejected the recommendation from Czech Republic because it added "without delay". ${ }^{32}$

In the review of its peers, South Africa has utilized regionalism to shield some regional allied states like Zimbabwe and Sudan from critical peer review. ${ }^{33}$ South Africa's recommendation to Zimbabwe ignored the government's repression and commented only on the economic sanctions impeding the human rights efforts of the Zimbabwean government. ${ }^{34}$ In the review of Sudan, it made only one general recommendation that Sudan should " $[\mathrm{g}]$ ive priority to the promotion and protection of human rights in all policies developed by the Government". ${ }^{35}$ This ignored the continuous humanitarian and human rights violations by the Sudanese government. ${ }^{36}$ Employing regionalism in this manner will limit the effectiveness of the UPR as a human rights regulatory mechanism.

Nonetheless, regional alliances within the UPR may not altogether be detrimental to the process. It may cause recommendations that may otherwise be rejected to be accepted because they were made by allies in the same regional group. The likelihood for recommendations on controversial issues to be accepted can be increased when made by states bound together by a common interest, as opposed to states with divergent interests. African states have been more inclined to accept recommendations from their regional peers. For example, all South Africa's 65

\footnotetext{
${ }^{25}$ UN Human Rights Council Report of the Working Group on the Universal Periodic Review - Kenya, $15^{\text {th }}$ sess, Agenda Item 6, UN Doc A/HRC/15/8 (17 June 2010) at [142.63] and [142.87].

${ }^{26}$ Id at [143.39] and [143.44].

${ }^{27}$ Id at [142.61].

${ }^{28}$ Id at [143.38].

${ }^{29}$ UN Human Rights Council "Report of the Working Group on the Universal Periodic Review - Nigeria" UN Doc $\mathrm{A} / \mathrm{HRC} / 11 / 26$ (5 October 2009) at [14].

${ }^{30}$ Ibid.

${ }^{31}$ See UN Human Rights Council "Report of the Working Group on the Universal Periodic Review - Chad" UN Doc A/HRC/25/14 (3 January 2014) at [110.18] and [110.120].

${ }^{32}$ See UN Human Rights Council "Report of the Working Group on the Universal Periodic Review - Chad: Addendum" UN Doc A/HRC/25/14/Add 1 (3 January 2014) at 2.

${ }^{33}$ South Africa was critical of the human rights situation of few African states and in those instances, the criticisms were mild and immediately balanced with positive remarks.

${ }^{34}$ South Africa referred specifically to economic sanctions. See UN Human Rights Council "Report of the Working Group on the Universal Periodic Review - Zimbabwe" UN Doc A/HRC/19/14 (19 December 2011) at [28].

${ }^{35}$ UN Human Rights Council "Report of the Working Group on the Universal Periodic Review - Sudan" UN Doc A/HRC/18/16 (11 July 2011) at [83.48].

36 See Human Rights Watch "World Report 2015: Sudan" (2015) Human Rights Watch, available at: <https://www.hrw.org/world-report/2015/country-chapters/sudan> (last accessed 16 September 2017).
} 


\section{Damian Etone}

recommendations to African states during UPR II were accepted including specific recommendations on the death penalty and gender violence. Nigeria and Kenya made and accepted more recommendations from the African group than from any other group of states during their reviews. ${ }^{37}$ Nigeria accepted all UPR I recommendations from African states. ${ }^{38}$ They equally participated more in the review of African states than in the review sessions of other states. ${ }^{39}$

The attitude of some Africa states, as earlier examined, whereby they accept recommendations from their regional peers but reject similar recommendations from others states provides evidence of regional solidarity against external states. States within the African region may be more aware and sometimes affected by the human rights issues in their neighbouring states. ${ }^{40}$ As such, they are in a better position to make relevant recommendations in the spirit of cooperation. There has been a few examples of statements by African states expressing solidarity during the review of their regional peer. During UPR I, Senegal "[r]eaffirmed its solidarity with the sister nation of GuineaBissau". ${ }^{41}$ Likewise, Burkina Faso stated during the review of Benin that the "difficulties faced by Benin in the implementation of its international human rights obligations were common to many developing countries". ${ }^{42}$ While there is a risk that regionalism may polarize the UPR and undermine the effectiveness of the mechanism by preventing cooperation across regional groups, cooperation across regional group of states can exist alongside regionalism when properly utilized. Therefore, regionalism can achieve a positive outcome in the UPR process.

\section{CULTURAL RELATIVISM}

UPR recommendations calling for the decriminalisation of same sex relations has been a cultural relativist challenge limiting the engagement of African States with the UPR. States that are advocates of cultural relativism in human rights implementation argue that human rights are dependent on the context and respective cultures in which they are applied. ${ }^{43}$ Blackburn notes that the UPR offers the open platform to contrast such cultural assertions. ${ }^{44}$

Many African states exhibited this cultural relativist aspect during their UPR sessions with respect to the issue of sexual orientation. Some states like Zimbabwe deny the existence of gay rights and consider it an attempt by the West to "prescribe new rights" ${ }^{45}$ Kenya rejected

\footnotetext{
${ }^{37}$ See UPR Info Statistics at UPR Info, available at: < http://s.upr-info.org/1G1cXQV> (last accessed 16 September 2017). ${ }^{38}$ Ibid.

${ }^{39}$ Ibid.

${ }^{40}$ Examples include human trafficking and the influx of refugees because of economic or political crisis.

${ }^{41}$ See UN Human Rights Council, "Report of the Working Group on the Universal Periodic Review - Guinea-Bissau" UN Doc A/HRC/15/10 (16 June 2010) at [55].

${ }^{42}$ See UN Human Rights Council "Report of the Working Group on the Universal Periodic Review - Benin" UN Doc $\mathrm{A} / \mathrm{HRC} / 8 / 39$ (28 May 2008) at [44].

${ }^{43}$ Roger Lloret Blackburn "Cultural Relativism in the Universal Periodic Review of the Human Rights Council” (2011) Institut Català Internacional per la $\mathrm{Pa}$ at $7<$ http://www.upr-info.org/sites/default/files/general-document/pdf/blackburn_upr_cultural_relativism.09.2011.pdf> (last accessed 16 September 2017).

${ }^{44}$ Ibid.

${ }^{45}$ See Harriet Alexander "Robert Mugabe at UN General Assembly says: We are not gays" (29 September 2015) The Telegraph (online), available at:
http://www.telegraph.co.uk/news/worldnews/africaandindianocean/zimbabwe/11898748/Robert-Mugabe-at-UN-Generalhttp://www.telegraph.co.uk/news/worldnews/africaandindianocean/zimbabwe/11898748/Robert-Mugabe-at-UN-General-
} 
similar recommendations and stated that "same-sex unions were culturally unacceptable in Kenya". 46 Similarly, Benin stated that the "phenomenon" was "marginal" and that decriminalisation was unlikely in the near future. ${ }^{47}$ Despite the fact that African states received the highest number of recommendations on sexual orientation, no African state made a recommendation on the issue. In recent years, there seem to be an increase in the number of states specifically walking towards criminalisation of same-sex unions in the region. Liberia in 2012 introduced two anti-gay Bills in its Parliament. Uganda in 2014 signed into law the AntiHomosexuality Law. Nigeria during its UPR I rejected all two recommendations on sexual orientation and further strengthened its position by enacting the Same Sex (Prohibition Act) in 2013. The more entrenched the socio- cultural and religious sentiments against decriminalisation, the more difficult for the state to accept recommendations for decriminalisation.

South Africa is the only exception, albeit it lacks commitment to it. South Africa's Constitution offers protection for sexual minorities even though effective implementation has been problematic. During UPR II, South Africa accepted recommendations on the issue of sexual orientation and was the only African state that made a recommendation on the issue but to a nonAfrican state, Cuba. ${ }^{48}$ In addition, it isolated itself from a statement made on behalf of the African Group at the HRC. Speaking on behalf of the African Group (excluding South Africa), the Nigeria delegate reiterated that same-sex relations stood against African values. ${ }^{49}$ He stated that:

\footnotetext{
"The heads of states of governments of the African Union...resolved not to... accept or integrate concepts which have not been universally defined and accepted in international human rights law. The African leaders thereby rescind the obsession by other regions or groups to impose their own value system on other regions". ${ }^{50}$
}

Despite South Africa's apparent support for the rights of sexual minorities, it did not make any recommendations to its African peers on the issue which would have clearly demonstrated its commitment on the issue within the African region. This cultural relativists approach to the UPR presents a challenge to the mechanism and questions the extent to which it can influence human rights changes within states on issues which are hyper-sensitive in cultural terms. A softer approach and recommendations to this sensitive issue which focuses more on raising awareness and sensitisation on the need for decriminalisation could present a better outcome than recommendations calling for immediate decriminalisation.

\section{NON-SELECTIVITY}

${ }^{46}$ UN Human Rights Council Report of the Working Group on the Universal Periodic Review - Kenya, $15^{\text {th }}$ sess, Agenda Item 6, UN Doc A/HRC/15/8 (17 June 2010) at [108].

${ }^{47}$ Human Rights Council "Report of the Human Rights Council on its Eighth Session" UN Doc A/HRC/8/52 (1 September 2008) at [714].

${ }^{48}$ UN Human Rights Council, Report of the Working Group on the Universal Periodic Review - Cuba, $24^{\text {th }}$ sess, Agenda Item 6, UN A/HRC/24/16 (8 July 2013) at [170.132].

${ }^{49}$ See Excerpts from a speech given by Mr. Ositadinma Anaedu, Representative of the Nigerian delegation to the United Nations on behalf of the African Group (minus South Africa), available at: $<$ http://www.familywatchinternational.org/fwi/Anaedu_Nigerian_speech excerpts.pdf $>$ (last accessed 16 September 2017). ${ }^{50}$ Ibid. 


\section{Damian Etone}

The principle of universality is an integral part of the UN human rights system. The notion that human rights are universal and that they apply to all peoples across the world was first enshrined in the Universal Declaration of Human Rights (UDHR). ${ }^{51}$ Universality is a key principle of the UPR which is characterized not only in terms of the universality of the process, but also the rights covered. This distinguishes it from the human rights treaty bodies. The scope of the work of the treaty bodies is limited only to states that have ratified the specific treaty within their competence. UN treaty bodies do not have the competence to examine the human rights compliance of states that have not ratified the relevant treaty. This allows for some state's human rights situation to escape scrutiny.

On the other hand, the UPR in terms of the rights covered, examines broader obligations under the UDHR and applicable international humanitarian law, including commitments and voluntary pledges made by individual states. ${ }^{52}$ With regard to the UPR process, it is truly universal since all UN member states are reviewed, regardless of whether the state has ratified any human rights treaties. With the exception of Israel which temporarily boycotted its UPR II in January 2013, all UN member states have been reviewed in the two cycles of the UPR, even North Korea. ${ }^{53}$ In October 2013, Israel returned and undertook its UPR II. The UPR mechanism ensures universal coverage of all states. The fact that every single member state of the UN has submitted to the UPR, even though with different level of commitment, may be one of its great success story.

However, the key principles of universality and non-selectivity may not have been fully achieved, in particular by the manner in which some African states have participated in the process. Smaller states within the African region have been less inclined to participate in the review of states outside the African region. Even bigger and more influential African states like Kenya and Nigeria have been very selective in the states that they review and are more attracted to the review of Asian states. Kenya did not participate in the review session of its peers during UPR I. This may raise questions on the universality and non-selectivity of the UPR process. Nevertheless, South Africa's engagement as a reviewer demonstrates the universality and nonselectivity of the UPR process. During UPR I, South Africa participated in the review sessions of all the five groups of states. It participated and made recommendations to 32 African States, 16 Asian States, 3 states from the EEG,${ }^{54} 11$ states from GRULAC and 10 states from WEOG. ${ }^{55}$ It participated in a similar manner during UPR II. ${ }^{56}$ South Africa is among the top five African states that have made the highest number of recommendations during the first two cycles of the UPR. The participation of states across regional lines in the review of their peers may well have positive

\footnotetext{
51 Universal Declaration of Human Rights, GA Res 217 A (III), UN GAOR, 3rd sess, 183rd plen mtg, UN Doc A/RES/217A (III) (10 December 1948).

${ }^{52}$ Institution Building Resolution of the United Nations Human Rights Council, above at note 1 at [1].

${ }^{53}$ International Service for Human Rights Israel: Decision to boycott human rights review threatens the rule of law (January 2013) < http://www.ishr.ch/news/israel-decision-boycott-human-rights-review-threatens-rule-law> (last accessed 16 September 2017).

${ }^{54}$ This included Russia, Slovakia and Azerbaijan

${ }^{55}$ This included Australia, France, Belgium, Germany, Denmark, Netherlands and New Zealand.

${ }^{56}$ During UPR II South Africa made recommendations to 30 African states, 13 Asian States, 2 States from the EEG, 9 states from GRULAC and 6 states from WEOG.
} 
effects on the universal conception of human rights and in promoting the equal treatment of all states in monitoring state implementation of their various international human rights obligations.

\section{COMPLEMENTARITY - THE CASE OF KENYA}

The need to prevent duplication of treaty body functions was a great concern during many stages in the negotiations leading to the establishment of the UPR in $2006 .{ }^{57}$ The principle of complementarity is reflected in UNGA resolution 60/251 which provides that the UPR mechanism "shall complement and not duplicate the work of treaty bodies." ${ }^{58} \mathrm{HRC}$ resolution $5 / 1$ reiterates this principle as one of the essential base of the review, and guarantees that the UPR adds value to the human rights monitoring system. ${ }^{59}$ The concept of complementarity is increasingly used in international law to underline the relationship between two or more autonomous organs. It is used by the International Criminal Court to define its relationship with the national courts. ${ }^{60}$ In the context of the UPR, complementarity regulates the relationship between the UPR mechanism and the UN human rights treaty bodies. It strives to achieve consistency and coherence in the operations of the monitoring organs with the aim of avoiding unnecessary duplication of functions which may lead to wastage of resources.

However, there is disagreement among scholars and practitioners regarding the ability of the UPR to complement the work of the human rights treaty bodies. This disagreement has been approached from three viewpoints: duplication, in that the UPR overlaps with the functions of the human rights treaty bodies; UPR process has a debilitating effect on existing human rights obligations insofar as it weakens and overshadows treaty body recommendations; and the UPR enhances state engagement with treaty bodies. Nadia Bernaz took the first perspective by arguing in 2009 that the UPR encroaches on the work of the treaty bodies resulting in significant overlap between the two mechanisms because of the common features they share. ${ }^{61}$ This argument echoed some of the sentiments of Australia and the African Group during the negotiations on the modalities of the UPR in $2006 .{ }^{62}$ They argued that a separate report for the UPR will be an unnecessary duplication of the reporting obligations required by the human rights treaty bodies and will represent an additional undue burden for states. ${ }^{63}$ This problem was resolved by limiting the state UPR report to a maximum of 20 pages but the complementarity of the UPR with the treaty bodies was far from being proved.

\footnotetext{
${ }^{57}$ For the different draft documents that raised concern on this issue see Felice D Gaer "A Voice not an Echo: Universal Periodic review and the UN Treaty Body System" (2007) 7/1 Human Rights Law Review 109 at 111.

${ }^{58}$ UN General Assembly Resolution Adopted by the General Assembly - Human Rights Council, GA Res 60/251, UN GAOR, 60th sess, 72nd plen mtg, Agenda Items 46 and 120, UN Doc A/Res/60/251 (3rd April 2006) at [5] (e).

${ }^{59}$ Institution Building of the United Nations Human Rights Council, above at note 1 at [3] (f).

${ }^{60}$ See Rome Statute of the International Criminal Court art 1; Jo. Stigen, The Relationship between the International Criminal Court and National Jurisdictions: the Principle of Complementarity (2008, M. Nijhoff Pub).

${ }^{61}$ Nadia Bernaz "Reforming the UN Human Rights Procedure: A Legal perspective on the Establishment of the Universal Periodic review" in Kevin Boyle New Institutions for Human Rights Protection (2009, Oxford University Press) at 78 and 88.

${ }^{62}$ Felice D Gaer "A Voice not an Echo: Universal Periodic review and the UN Treaty Body System" above at note 57 at 122.

${ }^{63}$ Ibid.
} 


\section{Damian Etone}

Sir Nigel Rodley, former UN HRC Member, argued in favour of the second perspective in the relationship between the treaty bodies and the UPR which is that UPR process has a debilitating effect on treaty body recommendations. He contended that the UPR enables states to evade their obligation to implement recommendations by treaty bodies. ${ }^{64}$ According to Rodley, the fact that states have the freedom to reject certain UPR recommendations can negatively impact the work of the treaty bodies because states "will invoke the gentler diagnosis of the UPR to discredit the harsher diagnosis of the treaty bodies." ${ }^{65}$ For example he found that by the end of 2009 , a total of nine UPR recommendations explicitly quoted recommendations from the Committee against Torture, of which five were rejected. ${ }^{66}$ On this basis, Rodley argues that UPR process presents a risk to the work of the treaty bodies as states could use the process to undermine the validity of recommendations from the treaty bodies. ${ }^{67}$ While there is much validity in Rodley's critique, the question may be asked what legal impact that could really have on treaty body recommendations given that the rejection of a UPR recommendation cannot invalidate a state's legal obligation owed to the treaty bodies under the relevant treaties.

Frouville criticized the UPR for oversimplifying the hard work of the treaty bodies by summarising their recommendations. ${ }^{68}$ According to Frouville, there is no real interaction between the UPR and other human rights mechanisms because states would only accept UPR recommendations that are consistent with their purpose. ${ }^{69} \mathrm{He}$ argued that in the worst case, the UPR is overshadowing the work of the treaty bodies by taking away material resources from treaty bodies and attracting more media and public attention. ${ }^{70}$

In 2015, Helen Quane provided evidence in the case of ASEAN states which supports the third point of view, and is more positive of the relationship between the UPR and the treaty bodies. She demonstrated that the UPR has enhanced the nature and level of the relationship between ASEAN states and the human rights treaty bodies. ${ }^{71}$ Quane argued that by recommending that states enhance their engagement with treaty bodies, submit overdue reports and ratify specific human rights treaties, the UPR has contributed to greater and more constructive engagement between many ASEAN states and the human rights treaty bodies. ${ }^{72}$ In this section, I engage with this third viewpoint and adopt an approach to the relationship between the UPR and the treaty

\footnotetext{
${ }^{64}$ Nigel S Rodley "UN Treaty Bodies and the Human Rights Council” in Helen Keller and Geir Ulfstein (eds) UN Human Rights Treaty Bodies: Law and Legitimacy (2012, Cambridge University Press) at 320-355.

${ }^{65}$ Id at 327.

${ }^{66}$ Id at 329 .

67 Ibid; Heather Collister makes a similar argument when she finds that the UPR contradicts/weakens treaty body recommendations and enable states to use the process as a means of rejecting treaty body recommendations. See Heather Collister "Rituals and Implementation in the Universal Periodic Review and the Human Rights Treaty Bodies" in Charlesworth and Larking, Human Rights and the Universal periodic Review: Rituals and Ritualism (2015, Cambridge University Press) at 116-119.

${ }^{68}$ Olivier de Frouville "Building a Universal System for the Protection of Human Rights: The Way Forward" in M Cherif Bassiouni and William A Schabas (eds) New Challenges for the UN Human Rights Machinery (2011, Intersentia) at 250255.

69 Ibid.

${ }^{70}$ Id at 250-251.

${ }^{71}$ Helen Quane "The Significance of an Evolving Relationship: Asian States and the Global Human Rights Mechanisms" (2015) 15 Human Rights Law Review at 303-309.

${ }^{72}$ Id at 295-309.
} 
bodies which has received little attention in the literature. This approach which I examine below with a focus on Kenya, considers whether the UPR can potentially create a synergy with other national, regional and international human rights mechanisms by amplifying and reinforcing their recommendations. While acknowledging that there are instances where the UPR recommendations have in fact either watered-down or contradicted treaty body recommendations, ${ }^{73}$ there is evidence of the UPR's potential to reinforce and provide greater visibility to recommendations from both national and international human rights mechanisms.

In the domestic context of change within Kenya, the UPR is a very important mechanism which can support and strengthen the transition and development process. The UPR recommendations can play a role vis-à-vis the national level by promoting the inclusion of international human rights standards in constitutional or legislative drafting, and by strengthening mechanisms that will improve access to justice, most especially for the vulnerable and marginalized groups. This can be very valuable to transitional societies undergoing various institutional reforms. In Kenya for example, the UPR occurred at a time of increased local calls for transitional justice, police and judicial reforms, constitutional changes, demand for socioeconomic rights, and to address the plight of internally displaced persons. Many of the recommendations during Kenya's UPR I reemphasized and reinforced transitional justice processes that were taking place within Kenya. For example the recommendations made by the Commission of Inquiry on Post-Election Violence $(\mathrm{CIPEV})^{74}$ regarding police reforms, and in particular, the establishment of an Independent Policing Oversight Authority (IPOA), were reemphasized in the report of the National Task Force on Police Reforms. ${ }^{75}$ These were subsequently amplified by many states in their recommendations to Kenya. The UK recommended that Kenya "establish an independent, credible and authoritative Police Oversight Authority, with sufficient powers and resources". ${ }^{76}$ Another state recommendation called Kenya to "fully implement the proposals made by the National Task Force on Police Reforms". ${ }^{77}$ Also, CIPEV had recommended that the Freedom of Information Bill be enacted forthwith. ${ }^{78}$ Norway reinforced this recommendation during UPR I by recommending that Kenya "Enact as a matter of urgency the Freedom of Information Bill". ${ }^{79}$ During UPR II, nine states buttressed the recommendations of the Kenyan Truth and Reconciliation Commission's report by each recommending that the state

\footnotetext{
${ }^{73}$ Examples of UPR recommendations which are contrary to the state's international obligations have been recorded in the review of Malaysia, Chile and The Netherlands. See Heather Collister, above n 67.

${ }^{74}$ Set up by the Kenyan government to investigate the facts and circumstances surrounding the 2007/2008 post-election violence. See Commission of Inquiry into the Post-Election Violence (CIPEV) "Report of the Commission of Inquiry into the Post-Election Violence" (October 16, 2008).

${ }^{75}$ Republic Of Kenya "Report of the National Task Force on Police Reforms: Abridged Version" (December 2009) ICC01/09-02/11-91-Anx3 at 13.

${ }^{76}$ UN Human Rights Council Report of the Working Group on the Universal Periodic Review - Kenya, $15^{\text {th }}$ sess, Agenda Item 6, UN Doc A/HRC/15/8 (17 June 2010) at [101.15].

${ }^{77}$ Id at $[101.20]$.

${ }^{78}$ Commission of Inquiry into the Post-Election Violence (CIPEV), "Report of the Commission of Inquiry into the PostElection Violence" (October 16, 2008) at 476.

${ }^{79}$ UN Human Rights Council Report of the Working Group on the Universal Periodic Review - Kenya, $15^{\text {th }}$ sess, Agenda Item 6, UN Doc A/HRC/15/8 (17 June 2010) at [101.10].
} 


\section{Damian Etone}

should implement the recommendations in the Commission's report. ${ }^{80}$ Kenya accepted these recommendations.

Similarly, Kenya's UPR I and II were also used by states to reinforce recommendations made by other regional and international human rights mechanisms regarding the human rights situation in Kenya. During Kenya's UPR I, Denmark recommended that the government implement the recommendations of both the Special Rapporteur on extrajudicial killing and that of the Special Rapporteur on the rights of indigenous people following the latter's visit to Kenya in $2007 .{ }^{81}$ Despite Kenya's denial to many of the findings on Kenya in the report of the UN Special Rapporteur on Extra-Judicial Killings, ${ }^{82}$ it accepted this recommendation. ${ }^{83}$ It also accepted the recommendation to "Implement the recommendations and decisions of its own judicial institutions and of the African Commission on Human and Peoples' Rights, particularly those relating to the rights of indigenous peoples". ${ }^{84}$

With particular regard to the treaty bodies, the UPR has equally reinforced their recommendations. With regard to the Committee on ESCR for example, the UPR reinforced many of their previous recommendations to Kenya. The Committee on ESCR had recommended in 2008 that Kenya criminalize domestic violence, female genital mutilation, and allocate sufficient resources for the fight against poverty. Without weakening any of these recommendations, the UPR strengthened and amplified their importance during Kenya's UPR I in 2010. States made more than 20 recommendations addressing these issues, many of which were specific. ${ }^{85}$ For example it was recommended that Kenya "Implement measures to prevent, punish and eradicate all forms of violence against women... and also completely eradicate the practice of female genital mutilation" $" 86$ and to "Urgently adopt legislation criminalizing female genital mutilation." ${ }^{87}$ Kenya accepted all these recommendations.

This section demonstrates the potential for the UPR to reinforce the human rights concerns raised and recommendations by domestic, regional and other international human rights mechanism. While there is a possibility for the UPR to weaken treaty body recommendations, it is important to also acknowledge that this may be a result of the softer approach of states to the UPR and reflective of its very nature as a cooperative, non-technical (state driven as opposed to human rights experts) and non-confrontational human rights mechanism. More so, the rejection of a

${ }^{80}$ UN Human Rights Council Report of the Working Group on the Universal Periodic Review - Kenya, 29 ${ }^{\text {th }}$ sess, Agenda Item 6, UN Doc A/HRC/29/10 (26 March 2015) at [142.91], [142.96], [142.101], [142.102], [142.104], [142.107], [142.107], [142.108], [142.116] and [142.117].

${ }^{81}$ UN Human Rights Council Report of the Working Group on the Universal Periodic Review - Kenya, $15^{\text {th }}$ sess, Agenda Item 6, UN Doc A/HRC/15/8 (17 June 2010) at [102.5] and [103.4].

${ }^{82}$ The Government of the Republic of Kenya, "Response To The Report Of The Special Rapporteur On Extrajudicial, Arbitrary Or Summary Executions, Professor Philip Alston, On His Mission To Kenya From 16-25 February, 2009" (Nairobi, 22 ${ }^{\text {nd }}$ May 2009) available at: < http://www.nation.co.ke/blob/view/-/604192/data/80408/-/7riry0z/-/gava> (last accessed 16 September 2017)

${ }^{83}$ After initially noting its concerns with the report. See UN Human Rights Council Report of the Working Group on the Universal Periodic Review - Kenya, $15^{\text {th }}$ sess, Agenda Item 6, UN Doc A/HRC/15/8 (17 June 2010) at [106].

${ }^{84}$ Id at [101.114].

${ }^{85} \mathrm{Id}$ at [101.48] - [101.57] and [101.97] - [101.108]

${ }^{86}$ Id at [101.51].

${ }^{87}$ Id at [101.56]. 
recommendation or whatever the outcome of a state's UPR, cannot relieve the state from its legal obligation under the relevant treaties as interpreted by the responsible treaty body. However, there is contention that the UPR has the capacity to undermine the legitimacy of the treaty bodies to sustain more progressive interpretations of the treaty texts and that sufficient push-back from states might adversely affect the claim to certain rights interpretations having the quality of opinio juris. ${ }^{88}$ With the completion of the first two cycles of the UPR, a comprehensive assessment on the impact of the UPR process on the work of the treaty bodies would significantly contribute to the debate. Nevertheless, in the case of Kenya as examined in this section, the state's engagement with the UPR demonstrates the ability of the UPR to strengthen and reinforce human rights concerns raised by other human rights mechanisms. This aspect of the UPR is seen to serve as a model and has inspired proposals on human rights and the post-2015 development agenda which advocates for a web of global effective monitoring that complements and reinforces efforts at the domestic and regional levels. ${ }^{89}$ In the case of Kenya, the UPR has been used as a platform to strengthen and support the judicial and police reform, and the truth and reconciliation process in the region among other human rights issues challenging the state.

\section{RITUALISM - THE CASE OF SOUTH AFRICA}

The engagement of South Africa with the UPR illustrates the potential for the UPR to degenerate into ritualism when there is a lack of effective NGO engagement. ${ }^{90}$ Braithwaite and others define ritualism as "acceptance of institutionalized means for securing regulatory goals while losing all focus on achieving the goals or outcomes themselves". ${ }^{91}$ Charlesworth and Larking, in their study on the regulatory power of the UPR, define ritualism as "participation in the process of reports and meetings but an indifference to or even reluctance about increasing the protection of human rights". ${ }^{92}$ Ritualism may take various forms. ${ }^{93}$ The form of ritualism examined in here is capitulation. ${ }^{94}$ Capitulation refers to the willingness to abide or acceptance of the legitimacy of an institution, in the absence of genuine commitment to the institutional goals. ${ }^{95}$

\footnotetext{
${ }^{88}$ See Olivier de Frouville "Building a Universal System for the Protection of Human Rights: The Way Forward" in M Cherif Bassiouni and William A Schabas (eds), New Challenges for the UN Human Rights Machinery (2011, Intersentia) at 250-255; Nadia Bernaz "Reforming the UN Human Rights Protection Procedures: A Legal Perspective on the Establishment of the Universal Periodic Review" in Kevin Boyle (ed) New Institutions for Human Rights Protection (2009, Oxford University Press) at 79-91.

${ }^{89}$ Centre for Economic and Social Rights "Who Will Be Accountable? Human Rights and the Post-2015 Development Agenda" (2013, New York and Geneva); OHCHR "President of the General Assembly: Interactive Dialogue 'Elements for a Monitoring and Accountability Framework for the Post-2015 Development Agenda"' (1 May 2014, New York); Centre for Reproductive Rights and others "Accountability For The Post-2015 Agenda: A Proposal For A Robust Global Review Mechanism” available at: < http://www.cesr.org/downloads/post-2015_accountability_proposal.pdf > (last accessed 16 September 2017).

${ }^{90}$ For a more detailed discussion see Damian Etone "The effectiveness of South Africa's engagement with the universal periodic review (UPR): potential for ritualism?"(2017) 33/2 South African Journal on Human Rights at 258-285.

${ }_{91}$ John Braithwaite, Toni Makkai, Valerie Braithwaite Regulating Aged Care (Edward Elgar, 2007) at 7.

92 Hilary Charlesworth and Emma Larking, "Introduction: the regulatory power of the Universal Periodic Review" in Hilary Charlesworth and Emma Larking (eds), Human Rights and the Universal Periodic Review: Rituals and Ritualism (2015, Cambridge University Press) at 16.

${ }_{93}$ Valerie Braithwaite "Defiance in Taxation and Governance (2009, Edward Elgar) at 77-9.

${ }_{95}^{94}$ Hilary Charlesworth and Emma Larking, above at note 91 at 11.

95 Ibid.
} 


\section{Damian Etone}

Capitulation can best describe South Africa's engagement with the UPR. South Africa claims to attach "great importance" to the work of the HRC as a body of "first instance" responsibility for the universal enforcement of human rights and "equal importance" to the UPR as the "hallmark of the Council's work". ${ }^{96}$ However, the extent of its engagement with the UPR suggests that it has found the UPR process useful in securing its foreign policy aims rather than an actual commitment to the intrinsic goals of the UPR mechanism.

The responses of South Africa to the recommendations from its peers suggests that it tries to shield itself from effective scrutiny and to mask human rights concerns with its past human rights achievement. In response to UPR I recommendations from its peers, South African stated that " $[\mathrm{m}]$ ost of the recommendations proposed for South Africa require serious contextualization... and have already been implemented through national legislation and programmes". ${ }^{97}$ This could be interpreted to mean the recommendations were not relevant. ${ }^{98}$ This section examines three issues that denote that the government's responses were substantially rhetorical. These three issues featured prominently in the recommendations to South Africa and included corporal punishment, violence based on sexual orientation and gender identity, and Xenophobia. Many of them were relevant and addressed the inadequacy or ineffectiveness of the measures put in place by the government to address these human rights concerns.

\subsection{Corporal Punishment}

The issue of corporal punishment featured among state and NGO recommendations during both UPR I and II. During UPR I, Slovenia made a specific recommendation that South Africa:
"Commit not only to removing the defence of reasonable chastisement but also to criminalizing corporal punishment with the concomitant pledges towards raising awareness and providing the necessary resource to support parents in adopting positive and alternative forms of discipline". 99

Similar recommendations were made by NGOs such as Children Now, the South African Human Rights Commission and Global Initiative to End Corporal Punishment of Children. ${ }^{100}$ In response

\footnotetext{
${ }^{96}$ Statement by Ambassador Baso Sangqu, Permanent Representative of South Africa on the Report of the Human Rights Council to the 42 nd Plenary meeting of the United Nations General Assembly, UN GAOR, $65^{\text {th }}$ Sess, $42^{\text {nd }}$ plen mtg, $(2$ November 2010) available at: 〈http://www.southafrica-newyork.net/speeches_pmun/view_speech.php?speech=3810844> (last accessed 16 September 2017).

${ }^{97}$ Human Rights Council "Report of the Human Rights Council on its Eighth Session" UN Doc A/HRC/8/52 (1 September 2008) at [567].

${ }^{98}$ This might be a probable excuse for why South Africa did not indicate its position on any of the recommendations.

${ }^{99}$ UN Human Rights Council "Report of the Working Group on the Universal Periodic Review - South Africa" UN Doc A/HRC/8/32 (23 May 2008) at [67] (1); See a similar recommendation from Mexico during UPR II for South Africa to prohibit and punish corporal punishment at home and in schools. See UN Human Rights Council "Report of the Working Group on the Universal Periodic Review - South Africa” UN Doc A/HRC/21/16 (12 July 2012) at [124.88].

${ }^{100}$ See Global Initiative to End All Corporal Punishment of Children "Corporal Punishment of Children in South Africa" (2015) at 1-6, available at: 〈http://www.endcorporalpunishment.org/assets/pdfs/states-reports/SouthAfrica.pdf> (last accessed 16 September 2017); Global Initiative to End All Corporal Punishment of Children "South Africa: Briefing for the Human Rights Council Universal Periodic Review - $1^{\text {st }}$ session, 2007" (2007); South African Human Rights Commission (SAHRC) "NHRI submission to the Universal Periodic Review Mechanism" (2007); Children Now "Alternate Report to the UN Committee on the Rights of the Child, prepared for the Universal Periodic Review of South Africa, Scheduled for
} 
to these recommendations, the government stated during UPR I that the issue of corporal punishment at home is being dealt with by the South African Domestic Violence Act $1998 .{ }^{101}$ It further stated that it has outlawed corporal punishment by legislation at school but there are only "isolated cases of non-compliance with legislation for which corrective measures are usually taken". ${ }^{102}$

However, 2014 findings by the Centre for Child Law at Pretoria University suggest that there is an "official ambivalence" towards the ban on corporal punishment. ${ }^{103}$ The Centre found that approximately 2.2 million children were exposed to corporal punishment and that the phenomenon has been on a steady increase in certain provinces in South Africa. ${ }^{104}$ This suggests that the response of the government to UPR recommendations on this issue is rhetoric. It attempts to deflect attention on the inadequacy and ineffectiveness of the measures put in place to end corporal punishment at school and home. Similar recommendations made by the Committee on the Rights of the Child, the Committee against Torture and more recently by the African Committee of Experts on the Rights and Welfare of the Child have not been implemented. ${ }^{105}$ They expressed concern at the continuous use of corporal punishment in schools. Their recommendations were that the government ensure that legislation banning corporal punishment is "strictly implemented" in schools and take effective measures to prohibit corporal punishment at home. ${ }^{106}$

The response of the government that simply points to existing legislation on corporal punishment undermines its receptiveness to the UPR recommendations. Corporal punishment remains lawful at home in South Africa and the existing enforcement mechanisms regulating their prohibition of corporal punishment in schools have been found to be inadequate and ineffective. ${ }^{107}$

\subsection{Violence based on Sexual Orientation}

Violence based on sexual orientation is one of the issues that featured prominently among state recommendations to South Africa during UPR I and II. Recommendations that states made to South Africa on sexual orientation included: undertake credible investigation and prosecute

April 2008" (2008); Instituto Internazionale maria Ausiliatrice et al "The Situation on the Rights of the Child in South Africa" (2011).

${ }^{101}$ Human Rights Council "Report of the Human Rights Council on its Eighth Session" UN Doc A/HRC/8/52 (1 September 2008) at [568].

${ }^{102} \mathrm{Ibid}$; see a similar response by the government during UPR II - UN Human Rights Council "Report of the Working Group on the Universal Periodic Review - South Africa" UN Doc A/HRC/21/16 (12 July 2012) at [121].

103 Centre for Child Law Promoting Effective Enforcement of the Prohibition against Corporal Punishment in South African Schools (2014, Pretoria University Press).

${ }^{104} \mathrm{Id}$ at 11.

${ }^{105}$ Committee on the Rights of the Child "Concluding Observations of the Committee on the Rights of the Child, South Africa" UN Doc CRC/C/15/Add.122 (2000) at [28]; Committee Against Torture "Concluding Observations of the Committee on the Rights of the Child, South Africa" UN Doc CAT/C/ZAF/CO/1 (7 December 2006) at [25]; African Committee of Experts on the Rights and Welfare of the Child "Concluding Recommendations by the African Committee of Experts on the Rights and Welfare of the Child (ACERWC) on the Republic Of South Africa Initial Report on the Status Of Implementation of the African Charter on the Rights and Welfare of The Child" (2014) at [35], available at: $<$ http://www.acerwc.org/?wpdmdl=8754> (last accessed 16 September 2017).

106 Ibid.

${ }^{107}$ See Global Initiative to End All Corporal Punishment of Children "Corporal Punishment of Children in South Africa" (2015) at 1-6, available at: 〈http://www.endcorporalpunishment.org/assets/pdfs/states-reports/SouthAfrica.pdf〉 (last accessed 16 September 2017); Centre for Child Law Promoting Effective Enforcement of the Prohibition against Corporal Punishment in South African Schools (2014, Pretoria University Press). 


\section{Damian Etone}

perpetrators; enhance prevention and monitoring capacity; train police and judiciary, and launch awareness-raising campaigns. ${ }^{108}$ In some ways, South Africa is an exception to the general criminalisation and discriminatory treatment confronting the LGBT community in Africa. Article 9 (3) of the South African Constitution explicitly prohibits discrimination against anyone based on sexual orientation. ${ }^{109}$ At the international level, South Africa has achieved a milestone in advancing the rights of LGBT worldwide. In 2011, despite strong criticisms from its regional peers, South Africa tabled a draft resolution before the HRC that expressed concern at violence and discrimination against persons based on their sexual orientation. ${ }^{110}$ South Africa was the only African state that voted in favour of a subsequent resolution on sexual orientation in $2014 .{ }^{111}$ With this in mind, South Africa's response to state recommendations on the issue during UPR I, simply made reference to the constitutional protection in place. ${ }^{112}$ During UPR II, its response referred to government policy framework on combating hate crime and its international endorsement of the rights of sexual minorities at the HRC. ${ }^{113}$

However, South Africa's role on the issue of sexual orientation lacks a consistent actual commitment domestically and internationally. The above responses of the government do not reflect on the need to address the inadequacies of the existing protective measures. Domestically, the situation of LGBTI individuals remains generally grim as they reportedly face violence and intimidation because of their sexual orientation. ${ }^{114}$ In 2011, Human Rights Watch published a report which found that there is a dichotomy between the constitutional ideals and public attitude towards these individuals. ${ }^{115}$ Furthermore, it found that despite the constitutional protection on the rights of LGBT persons, discrimination against them remained institutionalized in the communities, families, the police and educators. ${ }^{116}$

State responses to violence based on sexual orientation have fallen short in many aspects. ${ }^{117}$ Notably, there is lack of official monitoring and reporting. ${ }^{118}$ Moreover, there is the

\footnotetext{
${ }^{108}$ See for example UN Human Rights Council "Report of the Working Group on the Universal Periodic Review - South Africa" UN Doc A/HRC/21/16 (12 July 2012) at [124.50], [124.51] and [124.75]-[124.87].

${ }^{109}$ Constitution of the Republic of South Africa Act 1996 (South Africa) ch 2, art 9 (3).

${ }^{110}$ Human Rights Council, "Human rights, sexual orientation and gender identity" UN Doc A/HRC/RES/17/19 (14 July 2011).

${ }^{111}$ Human Rights Council, "Human rights, sexual orientation and gender identity" UN Doc A/HRC/RES/27/32 (2 October 2014).

${ }_{112}$ Human Rights Council, "Report of the Human Rights Council on its Eighth Session" UN Doc A/HRC/8/52 (1 September 2008) [572].

${ }^{113}$ UN Human Rights Council, "Report of the Working Group on the Universal Periodic Review - South Africa Addendum" UN Doc A/HRC/21/16/Add.1, annex A (12 July 2012) [124.51].

114 The Centre for Applied Psychology of the University of South Africa et al, "Violate Hate Crimes in South Africa" (2012) $\quad 1-9<\quad<\quad$ http://www.upr-info.org/sites/default/files/document/south_africa/session_13_may 2012/js6uprzafs132012jointsubmission6e.pdf>; Human Rights Watch, “We'll Show You You're a Woman”: Violence and Discrimination against Black Lesbians and Transgender Men in South Africa" (2011) < https://www.hrw.org/sites/default/files/reports/southafrica1211.pdf>.

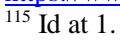

${ }^{116}$ Id at $14-15$.

${ }^{117}$ See The Centre for Applied Psychology of the University of South Africa et al "Violate Hate Crimes in South Africa" (2012) at 7-8, available at: <http://www.upr-info.org/sites/default/files/document/south africa/session 13 may 2012/js6uprzafs 132012jointsubmission6e.pdf > (last accessed 16 September 2017).

${ }_{118}$ Ibid; UPR II recommendation made by The Netherlands to South Africa addresses this issue. See UN Human Rights Council, above at note 107 at [124.81].
} 
growing phenomenon of "corrective" or "curative" rape, ${ }^{119}$ in relation to which Lea Mwambene argues that the government has failed to fulfil its constitutional mandate. ${ }^{120}$ Likewise, in 2011 , the Committee on the Elimination of All forms of Discrimination against women expressed "serious concern about the practice of so called "corrective rape" of lesbians" in South Africa. ${ }^{121}$

In addition, some public figures and those who design government policies in South Africa hold strong conservative views about sexual minorities. In 2012, Peter Holomisa, Chairperson of Parliament's Constitutional Review Committee, stated that "homosexuality was a condition that occurred when certain cultural rituals have not been performed" and further said, "when rituals are done, the person starts to behave like others in society". ${ }^{122}$ Jacob Zuma, now President of South Africa, was criticized in 2006 for publicly describing same-sex marriages as "a disgrace to the nation and to God". ${ }^{123}$ Such conservative views undermine the commitment of South African government to protect the rights of LGBT individuals.

At the International level, South Africa's commitment to protecting the rights of sexual minorities is fraught with inconsistencies and double standards. As earlier noted, it made no recommendations on the issue to its regional peers during their reviews in the HRC. This demonstrates a reluctance to take a definite position at odds with majority of African states. Graeme Reid has criticized South Africa for supporting a regressive HRC resolution on "Protection of the Family" which infringed on the rights of LGBT people. ${ }^{124}$ He equally observed that South Africa stopped attending meetings of the core group of LGBT-friendly states. ${ }^{125}$

South Africa's role in the advancement of the rights of LGBT people is an important one. However, the state needs to be consistent in its commitment internationally and take the lead in engaging its regional peers on the decriminalisation of same-sex relations. At the domestic level, South Africa's response to the UPR recommendations is substantially rhetorical. Most of the recommendations addressed the inadequacies of the existing protective measures and the need for the state to provide effective protection for sexual minorities. Engaging with the UPR recommendations by enhancing prevention and monitoring capacity and launching awarenessraising campaigns, can help narrow the gap between the constitutional ideals and public attitude towards LGBT individuals and help counter ritualism.

\footnotetext{
${ }^{119}$ Its recommendations that South Africa abides by its constitutional provisions, provide effective protection to sexual minorities and enact comprehensive anti-discrimination law have not been implemented by South Africa.

${ }^{120}$ Lea Mwambene "Realisation or Oversight of a Constitutional Mandate?: Corrective rape of black African lesbians in South Africa" (2015) 15/1 African Human Rights Journal at 58-88.

${ }^{121}$ Committee on the Elimination of Discrimination against Women "Concluding observations of the Committee on the Elimination of Discrimination against Women - South Africa” UN Doc. CEDAW/C/ZAF/CO/4 (4 February 2011) at [39][40].

${ }^{122}$ Deon De Lange "Call to suspend ANC MP for opening fire on gay rights" (8 May 2012) Cape Times, (Cape Town) at 4; This stated was made during a submission made to the Constitution review committee calling for changes to section 9 of the constitution that protects against discrimination based on sexual orientation.

123 IRIN "South Africa: Zuma slammed for views on homosexuality, same-sex marriage" (2006), available at: < http://www.irinnews.org/report/61195/south-africa-zuma-slammed-for-views-on-homosexuality-same-sex-marriage> (last accessed 16 September 2017).

${ }^{124}$ Graeme Reid is the Director of Lesbian, Gay, Bisexual, and Transgender Rights Programme at Human Rights Watch. See Graeme Reid "South Africa's Worrying Prevarication on LGBT Rights" (2014) Policy Review, available at: < http://www.policyreview.eu/south-africas-worrying-prevarication-on-lgbt-rights/> (last accessed 16 September 2017). ${ }^{125}$ Ibid.
} 


\section{Damian Etone}

\subsection{Racism and Xenophobia}

This was a prominent issue in the review of South Africa at the HRC with a dramatic increase from two recommendations during UPR I to 12 recommendations during UPR II. Most of these recommendations required the government to "reinforce measures to combat and prevent xenophobia" and to "take all necessary steps to address the issue of xenophobia through legislation" 126 Xenophobia has been a social problem in South Africa for almost two decades, entrenched by the legacy of apartheid. ${ }^{127}$ However, the extent of the government's response to racism and xenophobia is questionable, and undermines its commitment to recommendations aimed at combating racism and xenophobia.

In August 2006, the Committee on the Elimination of Racial Discrimination (CERD) was concerned about the frequency of hate crimes in South Africa and the "inefficacy of the measures in preventing such crimes". ${ }^{128}$ It recommended that the government "adopt legislative and other effective measures to prevent, combat and punish hate crimes". ${ }^{29}$ In 2007, similar recommendations came from the African Peer Review Mechanism after observing that "xenophobia... is currently on the rise and should be nipped in the bud". ${ }^{130}$ In May 2008, a resonance of xenophobic violence in South Africa left more than 60 people dead and about 100.000 people displaced. ${ }^{131}$ This indicated that the government did not proactively engage with the recommendations.

During the adoption of South Africa's UPR I report in June 2008, the South African delegation was questioned on the May 2008 xenophobic incident. The government in its response was hesitant to recognize the incident as xenophobic. It stated that "[t]he government of South Africa is on record as having publicly deplored the recent acts of violence against foreigners in the country by individuals and groups, ostensibly motivated by xenophobia". ${ }^{132}$

South Africa has undertaken some measures to address the problem of xenophobia but the effectiveness of these measures in preventing future reoccurrence in some parts of the country is questionable. In its official response to UPR II recommendations on racism and xenophobia, South Africa referred to the substantive content of a draft National Action Plan to Combat Racism, Racial Discrimination, Xenophobia and Related Intolerance (NAP), which was being finalized. ${ }^{133}$ It also pointed to its leadership on resolutions against racism and xenophobia at the international

${ }^{126}$ UN Human Rights Council "Report of the Working Group on the Universal Periodic Review - South Africa" UN Doc $\mathrm{A} / \mathrm{HRC} / 21 / 16$ (9 July 2012) at [124.33]-[124.46].

${ }^{127}$ Sheila Croucher "South Africa's illegal aliens: Constructing national boundaries in a post-apartheid state" (1998) 21 Ethnic and Racial Studies at 639-660; Sally Peberdy "Imagining Immigration: Inclusive Identities and Exclusive Politics in Post 1994 South Africa" (2001) 48 Africa Today at 15-34.

${ }^{128}$ Report of the Committee on the Elimination of Racial Discrimination, 61st sess, Supplement No. 18 (A/61/18), UN Doc A/61/18 (16 August 2006) at [390].

${ }^{129}$ Ibid.

${ }^{130}$ African Peer Review Mechanism (APRM), “APRM Country Report for South Africa No. 4” (May 2007) at [3.134].

${ }^{131}$ Jonathan Crush et al The Perfect Storm: The Realities of Xenophobia in Contemporary South Africa (Cape Town 2008).

${ }^{132}$ Human Rights Council "Report of the Human Rights Council on its Eighth Session" UN Doc A/HRC/8/52 (1 September 2008) at [574].

${ }^{133}$ UN Human Rights Council "Report of the Working Group on the Universal Periodic Review - South Africa Addendum" UN Doc A/HRC/21/16/Add.1, annex A (12 July 2012) at [124.36]. 


\section{African States and the UPR: Themes Emerging}

level. ${ }^{134}$ However, it has not met such rhetoric with concrete action. The NAP against racism that South Africa envisaged would be lodged with the UN by May 2013, have not been deposited. ${ }^{135}$ Moreover, instances of xenophobic attacks continued after 2011. ${ }^{136}$ The reoccurrence of a major xenophobic violence in April 2015 (Durban) underscores the ineffectiveness of the government's measures to combat xenophobia.

In addition, the narratives constructed by some South African government officials and elites on the xenophobic attacks undermine its commitment to combat racism and xenophobia. Shortly after the April 2015 xenophobic attacks in Durban, the Small Business Development minister, Lindiwe Zulu, stated that "the businesses of foreign Africans based in township could not expect to co-exist peacefully with local business owners unless they share their trade secret". ${ }^{137}$ King Goodwill Zwelithini, king of the Zulu people in South Africa, arguably played a role in inciting the 2015 xenophobic violence when he said at a public gathering that "African migrants should take their things and go". ${ }^{138}$ The initial denial and "ritual" condemnation of such rhetoric and narratives bring into question South Africa's commitment to combat racism and xenophobia, and undermine its reception to recommendations on the issue.

The responses of the South African government to the above three issues indicate a lack of commitment to address them effectively. On corporal punishment, the response of the government that simply points to existing legislation fails to address the inadequacies and ineffectiveness of the current measures. It equally ignores several recommendations from regional and international human rights mechanisms for stronger protection. Violence and discrimination based on sexual orientation remain institutionalized in the communities despite South Africa's constitutional protection and international support on the issue. Moreover, the recurrence of xenophobic violence in April 2015, despite international leadership, indicates the extent of the government's ritualism in handling racism and xenophobia.

\section{CONCLUSION}

\footnotetext{
134 Ibid.

${ }^{135}$ While there has been a remarkable level of consultation on the draft plan, it has taking too long to finalize given that South Africa hosted the $3^{\text {rd }}$ World Conference against Racism in 2001 which adopted a resolution which urged "states to establish and implement without delay" a national action plan against racism, xenophobia and related intolerance. See Department of Justice and Constitutional Development South Africa "Address by the Deputy Minister of Justice and Constitutional Development, the Hon John Jeffery, MP, at a Consultative Workshop on the National Action Plan to Combat Racism, Racial Discrimination, Xenophobia and Related Intolerance, 15 May 2015" (2015), available at: <http://www.justice.gov.za/m speeches/2015/20150515 NAP.html > (last accessed 16 September 2017).

136 See reports of NGOs and other stakeholders for South Africa's UPR. The Centre for Applied Psychology of the University of South Africa et al, above at note 113 at 3; Human Rights Institute of South Africa (HURISA) et al "Joint Submission to the Universal Periodic Review" (28 November 2011) at [5.1]; United Nations High Commission for Refugees (UNHCR) "Submission by the United Nations High Commission for Refugees for the Office of the High Commissioner for Human Rights' Compilation report-Universal Periodic Review: South Africa” (2011) at 3; Lawyers for Human Rights and Consortium for Refugees and Migrants in South Africa "The Situation of the Rights of refugees and Migrant in South Africa: Follow-up since 2008" (2011) at 9-10.

137 Willian Gumede "South Africa must Confront Root Causes of its Xenophobic Violence" The Guardian (online), 20 April 2015, available at: <http://www.theguardian.com/commentisfree/2015/apr/20/south-africa-xenophobic-violencemigrant-workers-apartheid $>$ (last accessed 16 September 2017). 138 Ibid.
} 


\section{Damian Etone}

Reflecting on some of the underlying principles of the UPR, it is difficult to reconcile them with some of the themes emerging from the UPR. Regionalism may polarize the UPR process, prevent cooperation across regional groups and undermine the effectiveness of the UPR mechanism. However, the regional alliance may not altogether be detrimental to the UPR process because it may cause recommendations which may not have been accepted to be accepted because they were made by allies in a particular regional group. This is more so within the African group due to the "soft approach" which they have adopted in making recommendations. Given the entrenched socio- cultural and religious sentiments against decriminalisation of same-sex union, it is difficult for many African leaders to accept recommendations for decriminalisation. A softer approach could make a big difference by focusing more on recommendations requesting African states to raise awareness and sensitization on the need for decriminalisation rather than tougher recommendations calling for decriminalisation. Nevertheless, the issue of selectivity in attending review sessions may raise questions on the universality and non-selectivity of the UPR process.

The UPR as a cooperative mechanism can complement other existing mechanisms as it was designed in the first place. The case of Kenya notes the potential for the UPR to strengthen existing human rights mechanisms, give renewed visibility and reinforce the human rights concerns raised by various national and international human rights mechanisms. The potential for this synergy within a cooperative, inclusive and collaborative human rights mechanism can ensure that the UPR recommendations are relevant and target the improvement of the human rights situation on the ground.

However, ritualism as examined in the case of Kenya presents a danger to the effectiveness of the UPR in improving the human rights situation on the ground. The state needs to be held accountable to implement the recommendations and commitment entered during the UPR. According to Takele Bulto, ritualism may be a temporal weakness of the UPR mechanism. ${ }^{139}$ However, it is vital that the mechanism addresses this weakness on time before it becomes entrenched. As rightly pointed out by Charlesworth and Larking, the ability of the UPR to move beyond rhetoric and ritualism, and actually improve the human rights situation on the ground depends profoundly on effective NGO engagement. ${ }^{140}$ NGOs should therefore actively engage in the various stages of the review, form coalitions and follow-up on the extent to which the state implements the UPR recommendations. While effective NGO engagement can contribute to the effectiveness of the UPR process, it is important to be wary of NGOs that are in reality

\footnotetext{
139 Takele Soboka Bulto “Africa's Engagement with the Universal Periodic Review: Commitment or Capitulation?" in Hilary Charlesworth and Emma Larking (eds), Human Rights and the Universal Periodic Review: Rituals and Ritualism (2015, Cambridge University Press) at 253.

${ }^{140}$ Hilary Charlesworth and Emma Larking, "Introduction: the regulatory power of the Universal Periodic Review" in Hilary Charlesworth and Emma Larking (eds), Human Rights and the Universal Periodic Review: Rituals and Ritualism (2015, Cambridge University Press) at 16.
} 
African States and the UPR: Themes Emerging

"government mouth pieces" or those that prioritize the agenda of their donors which may not necessarily be the priority of the people they claim to serve. ${ }^{141}$

${ }^{141}$ See Makau Mutua Human Rights NGOs in East Africa (2008, University of Pennsylvania Press) at 47. 